\title{
Determinants of trade intensity of Egypt with COMESA Countries
}

\author{
Samah SA Elmorsy
}

Correspondence:

salamlm3@yahoo.com

Economic Lecturer Institute of

African Research and Studies, Cairo

University, Cairo, Egypt

\begin{abstract}
Egypt has joined to COMESA since May 1998 in order to promote its economic relations with the rest of member states, especially the trade relations, so the aim of the paper is to assess COMESA regional integration efforts and to identify the most effective and important variables that determine trade intensity of Egypt with COMESA countries. To achieve the aim of the paper, estimation of Trade Intensity Index (TII) of Egypt with COMESA was adopted, and econometric methodology (gravity model) was used to estimate the variables that have the major effect on Egypt's trade with COMESA.

The paper concludes that there are opportunities to increase Egypt's Trade with COMESA, after applying gravity model paper concludes that Gross Domestic Product and existence of sharing borders are the most effective variables that determine Egypt trade with COMESA, paper also defined the major obstacles of regional integration in COMESA and presented some policy implication.
\end{abstract}

Keywords: Regional integration; Egypt; COMESA; South-South trade

\section{Introduction}

Regional integration remains the key strategy that will enable African governments to accelerate the transformation of their fragmented small economies, expand their markets, widen the region's economic space, and reap the benefits of economies of scale for production and trade, thereby maximizing the welfare of their nations. Regional integration increases competition in global trade and improves access to foreign technology, investment, and ideas. African leaders thus consider it an important path to broad-based development and a continental economic community, in accordance with the Treaty Establishing the African Economic Community (1991) and the COMESA (2000).

Common Market for Eastern and Southern Africa (COMESA) began in December 1994, until 2014 it has 19 member states, Egypt has joined to COMESA since May 1998 in order to promote its economic relations with the rest of member states, especially the trade relations, but Egypt trade with COMESA countries faces many obstacles, so the aim of this paper is to analyze determinates of trade intensity of Egypt with COMESA through the following perspectives:

I. Theoretical Issues: Economic Integration, II. Regional Integration in COMESA: A Background, III. The Methodology, A. Estimation of Egypt Trade Intensity Index (TII) with COMESA, B. Estimation Determinates of Egypt's Trade Intensity with COMESA

(C) 2015 Elmorsy; licensee Springer. This is an Open Access article distributed under the terms of the Creative Commons Attribution License (http://creativecommons.org/licenses/by/4.0), which permits unrestricted use, distribution, and reproduction in any medium, provided the original work is properly credited. 
IV.COMESA's International and Intra-Organizational Trade, V. Egypt Trade with

COMESA Countries, VI. The Obstacles to Regional Integration in COMESA, VII. The findings and Conclusion Remarks.

\section{Theoretical issues: economic integration}

Two major theoretical motivations for the formation of trade blocs are the allocation effect and the accumulation (or growth) effect of free trade within a regional bloc. With respect to the allocation effect, economic theory shows that, in a competitive economy, the demand for a good directs productive resources to the production of that good. Given that the imposition of tariff and non-tariff barriers between countries interferes with this signal, the removal of such trade barriers in the context of regional integration is thought to increase efficiency in resource allocation (United Nations Conference on Trade and Development UNCTAD 2009:5).

A corollary of the allocation effect is the-so-called "scale and variety effects". The scale effect relates to the fact that the protection of inefficient industries as seen in Africa and other developing economies during the import-substitution era maintained too many inefficient firms, many of which operated at inefficient large scales. Opening up markets in the context of an overall trade liberalization policy or within a regional trade bloc reduces this protection. On the other hand, by creating large markets, regional integration could allow small firms to reach their optimal size. This in turn would lower average costs, reducing consumer prices (Dupasquier and Dsakwa 2006:9-11).

With respect to the variety effect, the idea is simply that integrating a country's economy into a wider market allows consumers to choose from a varied array of goods, which should increase their welfare. Increased competition across a wide range of products can also lower consumer prices. From a firm's perspective, the opportunity to choose from a wider array of production factors would enable it to use the most appropriate inputs, which could increase its productivity.

The second major effect of regionalism that of accumulation, is observed through the investment and trade channels. When economic integration expands regional markets, more suppliers are attracted to the regional market and firms have the opportunity to specialize. This reduces average production costs within the trade bloc, increasing the return to factors of production and hence physical and non-physical (including knowledge) factor accumulation. Moreover, technological spillovers resulting from regionalism lead to increases in productivity and the reduction of production costs, further attracting more investment, and hence, factor accumulation. The combination of the effects of regional economic integration on efficiency and accumulation lead to the recognition that regional integration can have a positive effect on economic growth (United Nations Conference on Trade and Development UNCTAD 2009:6).

Moreover, free movement of capital, labour and other factors of production is often an explicit objective of economic integration schemes. Indeed, free mobility of production factors can help to reduce production costs in partner countries where these factors are relatively scare, attracting productive activity there.

It should be noted that, despite the positive effects of regional integration presented above, some criticisms have been aired as well. Proponents of free trade, for example, argue that regional trade blocs limit rather than encourage global trade expansion. They base their argument on the fact that regional blocs tend to raise tariff and non-tariff walls 
around them, reducing trade flows from outside the bloc. This, as a result, may lead to inefficiencies in resource allocation and production, reducing the welfare gains from competition (United Nations Conference on Trade and Development UNCTAD 2009:7).

Regional integration arrangements take a variety of forms started with preferential trade area and aiming to reach economic and political union, countries can start with any arrangement, but most begin by removing impediments to trade among themselves. They then introduce deeper and wider integration mechanisms (Economic Commission for Africa (ECA) 2004:10).

In 1991 African Heads of States and governments signed the Treaty (Abuja Treaty) Establishing the African Economic Community (AEC) which provides the guiding principles and goals that strengthen the integration agenda. The idea is to build the AEC as an integral part of the African Union. The AEC is to be formed in six phases over 34 years:

- First phase (five years): Strengthen existing Regional Economic Communities RECs and create new RECs in regions where they do not exist. (to be completed in 1999)

- Second phase (eight years): Ensure consolidation within each REC, with a focus on liberalizing tariffs; removing non-tariff barriers (NTBs); harmonizing taxes; and strengthening sector integration regionally and continentally in trade, agriculture, money and finance, transport and communications, industrial development and energy. (to be completed in 2007)

- Third phase (10 years): Set up in each REC a free trade area (FTA) and customs union (with a common external tariff and a single customs territory). (to be completed in 2017)

- Fourth phase (two years): Coordinate and harmonize tariff and non-tariff systems among the RECs with a view to establishing a continental customs union. (to be competed in 2019)

- Fifth phase (four years): Set up an African common market. (to be completed in 2023)

- Sixth phase (five years): Establish the AEC, including an African Monetary Union and Pan- African Parliament. (to be completed in 2028) (Economic Commission for Africa ECA 2012:11-12)

The following Figure 1 indicates the status of the integration of the RECs in Africa, where the vertical column refers to economic integration stages.

EAC (Eastern African Community) is the most advanced Community in the integration stages. After five years operationalizing its Customs Union, the EAC launched its Common Market in 2010. COMESA launched its Customs Union in 2009. ECOWAS (Economic Community of Western African States) and SADC (Southern African Development Community) have made progress in building their FTAs. ECCAS (Economic Community of Central African States) launched its FTA but is facing enormous challenges in implementing it. UMA (West African Economic and Monetary Union), CEN-SAD (Community of Sahel- Saharan States) and IGAD (Intergovernmental Authority on Development) are still in the stage of cooperation amongst their Member States. The following Table 1 indicates to the status of implementation of the Abuja treaty per REC. 


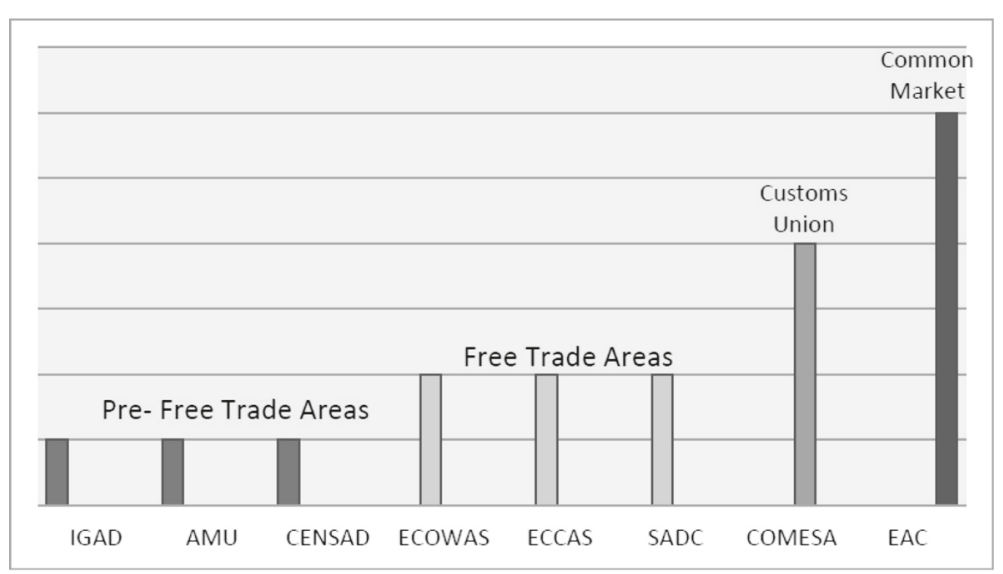

Figure 1 Status of integration of the African RECs. Source: African Union Commission 2013, Status of Integration in Africa, Addis Ababa: African Union19.

\section{Regional integration in COMESA: background}

The history of COMESA began in December 1994 when it was formed to replace the former Preferential Trade Area (PTA) which had existed from the earlier days of 1981. COMESA (as defined by its Treaty) was established "as an organization of free independent sovereign states which have agreed to co-operate in developing their natural and human resources for the good of all their people" and as such it has a wideranging series of objectives which necessarily include in its priorities the promotion of peace and security in the region (COMESA Administrators 2000:1-2).

However, due to COMESA's economic history and background its main focus is on the formation of a large economic and trading unit that is capable of overcoming all of the barriers that are faced by individual states (COMESA Administrators 2003:1).

COMESA is concentrating on trade in goods and services; monetary integration, including payments and settlement arrangements; investment promotion and facilitation; and infrastructure development (air, road, rail, maritime and inland transportation, ICT and energy) COMESA launched its customs union in June 2009, which will allow the application of a single tariff, the common external tariff (CET) in all COMESA States for an interim of three years. A program for eliminating non-tariff barriers has been implemented through organizational structures at the national and regional level. By 2025, COMESA expects to remove all tariff barriers. Consultations on a single FTA among COMESA, EAC and SADC are ongoing, and it is expected that the three RECs will coordinate their programmes to form a single customs union comprising all three. (COMESA 2010:7-8), the paper will assess COMESA's efforts to promote regional integration throw the following main pillars.

\section{Free movement of persons, goods, services and capital}

Recently, COMESA has made significant progress in this area. A number of COMESA member States treat visa issues with great flexibility. Using the protocol on the gradual relaxation of visas, a number of COMESA countries are giving visas to individuals upon arrival at the airport.

COMESA also approved two protocols, one on the free movement of persons, labour, services, right of establishment and right of residence, which was adopted in 2001 
Table 1 Status of implementation of the Abuja Treaty per REC

\begin{tabular}{|c|c|c|c|c|c|c|c|c|}
\hline \multirow{2}{*}{$\begin{array}{l}\text { Stages of } \\
\text { the Abuja } \\
\text { treaty } \\
\text { RECS }\end{array}$} & \multirow{2}{*}{$\begin{array}{l}\text { Stage one: 1994-1999 } \\
\text { Strengthening existing RECS } \\
\text { and creation of new RECS } \\
\text { where they do not exist }\end{array}$} & \multicolumn{2}{|c|}{ Stage two: $2000-2007$} & \multicolumn{2}{|c|}{$\begin{array}{l}\text { Stage three: } \\
\text { 2008-2017 }\end{array}$} & \multirow{2}{*}{$\begin{array}{l}\text { Stage four: } \mathbf{2 0 1 8 - 2 0 1 9} \\
\text { Continental Customs Union }\end{array}$} & \multirow{2}{*}{$\begin{array}{l}\text { Stage five: } \mathbf{2 0 2 0 - 2 0 2 3} \\
\text { Establishment of an African } \\
\text { Common Market }\end{array}$} & \multirow{2}{*}{$\begin{array}{l}\text { Stage six: } 2024-2028 \\
\text { latest } 2034 \\
\begin{array}{l}\text { Monetary and Economic } \\
\text { Union }\end{array}\end{array}$} \\
\hline & & $\begin{array}{l}\text { Coordination and } \\
\text { harmonization of } \\
\text { activities }\end{array}$ & $\begin{array}{l}\text { Gradual elimination of } \\
\text { tariff and non-tariff } \\
\text { barriers }\end{array}$ & $\begin{array}{l}\text { Free Trade } \\
\text { Area }\end{array}$ & $\begin{array}{l}\text { Customs } \\
\text { Union }\end{array}$ & & & \\
\hline UMA & $\nabla$ & $\nabla$ & In progress & Not yet & Not yet & \multirow{8}{*}{$\begin{array}{l}\text { This stage will be achieved } \\
\text { when all RECs have } \\
\text { achieved Customs Union } \\
\text { and harmonized their } \\
\text { respective Common } \\
\text { External tariff (CET), with a } \\
\text { view of creating one single } \\
\text { continental CET }\end{array}$} & \multirow{8}{*}{$\begin{array}{l}\text { This stage will be achieved } \\
\text { when all RECs have } \\
\text { achieved continental } \\
\text { customs union as well as } \\
\text { free movement of labour } \\
\text { and capital }\end{array}$} & \multirow{8}{*}{$\begin{array}{l}\text { This stage will be achieved } \\
\text { when all RECs have } \\
\text { achieved African Common } \\
\text { Market at which time there } \\
\text { will be a common currency, } \\
\text { issued by the African } \\
\text { Central Bank }\end{array}$} \\
\hline IGAD & $\nabla$ & $\nabla$ & In progress & Not yet & Not yet & & & \\
\hline SADC & $\checkmark$ & $\nabla$ & $\checkmark$ & $\nabla$ & 2013 & & & \\
\hline CENSAD & $\nabla$ & $\nabla$ & Not yet & Not yet & Not yet & & & \\
\hline ECOWAS & $\checkmark$ & $\nabla$ & $\checkmark$ & $\checkmark$ & 2015 & & & \\
\hline COMESA & $\checkmark$ & $\nabla$ & $\checkmark$ & $\nabla$ & $\checkmark$ & & & \\
\hline ECCAS & $\nabla$ & $\nabla$ & $\nabla$ & $\nabla$ & $\begin{array}{l}\text { No date } \\
\text { fixed }\end{array}$ & & & \\
\hline EAC & $\nabla$ & $\nabla$ & $\nabla$ & $\nabla$ & $\nabla$ & & & \\
\hline
\end{tabular}

Source: African Union Commission 2013, Status of Integration in Africa, Addis Ababa :African Union20. 
during the 6th COMESA Summit of Cairo, Egypt, and the gradual relaxation and eventual elimination of visas, adopted in 1984. However, only few member States (4 among the 19) have signed them. To remove all barriers to free movement, COMESA developed a timetable for the period between 2000 and 2014, illustrated in Table 2 below:

A project to coordinate visas is under way and expected to be completed by 2014. A database has been set up to monitor the movement of persons, particularly those who are undesirable in COMESA (Economic Commission for Africa ECA 2010:13-29).

\section{Physical integration}

COMESA continues to experience deficiencies in transport, communications and hydro-energetic supply. In COMESA transit facilitation instruments are being developed to improve road infrastructure. These include axle load limits, gross vehicle weights, harmonized road user charges, carrier licenses and the Regional Customs Transit Guarantee (RCTG). COMESA main challenge will be to fully implement these measures to ease cross-border traffic (Economic Commission for Africa ECA 2008:31).

In order to take care of the current and increasing road infrastructure assets through proper maintenance and management, the COMESA countries had undertaken Road Sector Management and Funding Reforms. Most countries had set up both road funds and road development agencies in order to maintain both the regional and national road networks. In this respect, a good number of countries had already established dedicated road funds and road authorities responsible for construction and maintenance of road infrastructure. Among the countries that had established such funds and road authorities are: Congo DR, Djibouti, Ethiopia, Kenya, Malawi, Rwanda, Sudan, Uganda, Zambia and Zimbabwe. The main source of funding for road maintenance was the fuel levy while construction and rehabilitation were funded through government budget allocations, borrowing from development banks and funds from cooperating partners (African Union Commission 2013:49).

The air transport liberalization programme had now been broadened to cover the entire Eastern and Southern Africa and encompasses COMESA, EAC and SADC regions. In the Previous year, a number of airlines had extended their route networks by adding new city pairs. Ethiopian Airlines is currently flying to Mombasa while Kenya Airways had introduced services to Juba, Luanda and resumed services to Gaborone. Egypt Air also commenced scheduled services to Lusaka via Dares Salaam in January 2011 although the services had been suspended for the time being due to the withdrawal of the fifth freedom traffic between Dares Salaam and Lusaka (African Union Commission 2013:56).

Table 2 Proposed COMESA timetable, 2000-2014

\begin{tabular}{ll}
\hline Timeframe & Projects \\
\hline $2000-2002$ & Gradual removal of visa requirements \\
$2002-2006$ & Movement of skilled labour and movement of services \\
$2006-2010$ & Right of establishment \\
2014 & Right of residence (20 years from date of entry in COMESA) \\
\hline
\end{tabular}

Source: Economic Commission for Africa (ECA) 2010, "Enhancing intra- African Trade, Assessing Regional Integration in Africa IV, Addis Ababa: ECA 14. 


\section{Energy}

Like other RECs COMESA faces energy shortages, particularly in electricity. According to available statistics, its energy demand exceeds its supply by more than 20 per cent, and it is projected that in 2015, demand will increase by up to 46 percent. Energy infrastructure must be improved. An energy master plan is being developed to tackle a joint energy strategy and priority investment plan that will mobilize public and private resources.

COMESA has launched an initiative to promote regional cooperation in energy development, trade and capacity building and had developed a baseline renewable energy database for the region. The Eastern African power pool has a 2025 strategic road map and regional market design. A regional power master plan and grid code have also been developed, and an independent regulatory body has been set up (Economic Commission for Africa ECA, 2013a, b:6).

The National Energy Policies of some COMESA countries, such as Democratic Republic of Congo, Egypt, Kenya, Malawi, Mauritius, Swaziland, Uganda, Zambia, and Zimbabwe are in line with the COMESA Model Energy Policy Framework. Some countries which are developing their National Energy Policies (in progress) such as Eritrea, Ethiopia and Rwanda have indicated that they will be using the COMESA Model Energy Policy Framework in order to secure compliance. Moreover, Sudan has already completed the development of its draft Energy Sector Policy and that the COMESA Model Energy Policy Framework was used to develop its draft Energy Sector Policy (African Union Commission 2013:63).

\section{Information and Communications Technologies (ICT)}

COMESA has established the Association of Regulators of Information and Communication in Central and Eastern Africa (ARICEA). The ARICEA is a consultative and collaborative forum that gathers regulators and associated actors in the ICT sector in the Eastern and Southern African region (COMESA 2011a, b, c, d, e, f:5).

COMESA adopted also e-Learning strategy which have objectives to operationalize an interactive and collaborative online platform that will increase access to and effectiveness of COMESA capacity building programs, supported by a regional pool of e-Learning experts. COMESA have also an E-Waste programme that has an objective of ensuring that the COMESA. region addresses E-Waste through the value chain from point-of-sale to end-of-life, including handling non-recyclable parts and substances and can productively dealing with it (African Union Commission 2013:74-75).

\section{The methodology}

\section{Estimation of Egypt trade intensity index (TII) with COMESA}

According to Balassa (1965)

Trade Intensity Index $(\mathrm{TII})=\frac{\left(\mathrm{X}_{\mathrm{nm}} / \mathrm{X}_{\mathrm{nw}}\right)}{\left(\mathrm{X}_{\mathrm{wm}} / \mathrm{X}_{\mathrm{ww}}\right)}$

Where:

- $\mathrm{X}_{\mathrm{nm}}$ : exports of country $\mathrm{n}$ (Egypt) to country m (COMESA)

- $X_{n w}$ : total exports of country n (Egypt)

- $\mathrm{X}_{\mathrm{wm}}$ : Total imports of COMESA

- $\mathrm{X}_{\mathrm{ww}}$ : Total exports of the world 
If the value of TII is one or more it means that there is potential opportunity to increase trade between country $\mathrm{n}$ and $\mathrm{w}$.

\section{Source of data}

To calculate TII of Egypt with COMESA, the paper collected the following data:

- COMESA total imports from: COMESA International Trade Statistics Bulletin 2012.

- Exports of Egypt to COMESA from: Egypt Trade Statistics profile Report 2011.

- World total exports from: UNCTAD Handbook of Statistics Year book 2013.

Result of calculation is represented in the following Table 3:

According to Table 3 TII of Egypt with COMESA was greater than one during (2005-2011), this means that there are potential opportunities to increase Egypt's trade with COMESA in the future, value of the index has taken a trend to increase since 2007 to 2010 but it started to decrease in 2011 as a result of political instability circumstances occurred in Egypt after the 25 January 2011 revolution. It was necessary to compare between TII of Egypt with COMESA after joining to COMESA by TII before joining to COMESA, but as a result of lack of data about Egypt exports to all COMESA countries before joining to the regional community, paper referred to (Fattah 2000:131) and according to his estimations, TII of Egypt was 1.27 and 1.91 in 1990 and 1995 respectively. This means that, before and after joining to COMESA there are potential opportunities to increase Egypt trade with the member states of the community, but after joining the opportunities became greater than before.

\section{Estimation determinates of Egypt's trade intensity with COMESA \\ Brief overview of the gravity model methodology}

The gravity model has been widely used to identify determinants of bilateral trade, though it is often criticized for lacking a strong theoretical basis. Despite its use in many early studies of international trade, the model was considered suspect in that it could not easily be shown to be consistent with the dominant Heckscher-Ohlin model explaining net trade flows in terms of differential factor endowments. Although criticism the model continues to be the most appropriate one because it contains the majority of the variables that determine bilateral trade flows. In a typical gravity model, bilateral trade flows are determined by the size of the two economies and the distance between them. However, it is always possible to expand the

Table 3 Trade intensity index between Egypt and COMESA value in US\$ million and \%

\begin{tabular}{lllllll}
\hline Years & $\mathbf{2 0 0 5}$ & $\mathbf{2 0 0 7}$ & $\mathbf{2 0 0 8}$ & $\mathbf{2 0 0 9}$ & $\mathbf{2 0 1 0}$ & $\mathbf{2 0 1 1}$ \\
\hline Exports of Egypt to COMESA & 431.43 & 494.26 & 1639.68 & 1861.08 & 2343.67 & 1622.5 \\
Egypt total exports & 10606.75 & 16144.84 & 26293.5 & 23110.02 & 26665.33 & 30607.39 \\
COMESA total imports & 67852 & 89669 & 130833 & 122983 & 142542 & 142706 \\
World total exports & 10495704 & 13946644 & 16122770 & 12511198 & 15174439 & 18320316 \\
Trade Intensity Index & 6.3 & 4.7 & 7.7 & 8.2 & 9.3 & 6.8 \\
\hline
\end{tabular}

Source: Calculated by the researcher. 
model to include other relevant determinants of trade. The following standard gravity model is specified and estimated to examine the potential for Egypt trade with COMESA:

$$
\begin{aligned}
& T_{i j}=\beta_{0}+\beta_{1}\left(Y_{i} Y_{j}\right)+\beta_{2}\left[\left(Y C_{i} Y C_{j}\right)\right]+\beta_{3} \text { Dist }_{i j}+\beta_{4}\left(\text { Area }_{i} \text { Area }_{j}\right)+\beta_{5}\left|Y C_{i}-Y C_{j}\right| \\
& +\left[\beta_{i} \sum Z_{i}+\beta_{j} \sum Z_{j}\right]
\end{aligned}
$$

Where: $\mathrm{T}$ is bilateral trade between country $\mathrm{i}$ and $\mathrm{j}$; $\mathrm{Y}$ is GDP; $\mathrm{YC}$ is GDP per capita and $Z_{i}$ and $Z_{j}$ are other relevant variables grouped under "infrastructure" (paved road length as per cent of total, number of mobile telephone per 1,000 people), policy (FDI in reporting countries, tax on international trade in partner country), "cultural and geographic" distance between the capitals of the trading countries, common official language, sharing border, being landlocked) and membership in regional groupings.

Expected signs: $\beta_{1}$ and $\beta_{2}$ are expected to be positive; $\beta_{3}, \beta_{4}$ and $\beta_{5}$ are expected to be negative. Infrastructure variables, sharing border and common official language, membership to a particular REC as well as FDI are expected to be positive, while being landlocked is expected to be negative (Economic Commission for Africa ECA 2010,392).

According to gravity model paper design the following equation to estimate determinates of Egypt trade Intensity with COMESA countries.

$$
\mathrm{Y}_{\mathrm{ij}}=\mathrm{f}\left(\mathrm{X}_{1}, \mathrm{X}_{2}, \mathrm{X}_{3}, \mathrm{X}_{4}, \mathrm{X}_{5}, \mathrm{X}_{6}, \mathrm{X}_{7}, \mathrm{X}_{8}\right)
$$

Where:

$\mathrm{Y}_{\mathrm{ij}}=$ Bilateral trade between Egypt and COMESA countries (value of exports from Egypt to COMESA countries).

$\mathrm{X}_{1}=$ Gross Domestic Product in COMESA countries (GDP) in 2010, in real constant price 2000 (US\$ million).

$\mathrm{X}_{2}=$ Gross domestic product per capita in COMESA countries in 2010 real constant price 2000 (US\$ million).

$\mathrm{X}_{3}=$ COMESA countries' population in 2010, (million).

$\mathrm{X}_{4}=$ COMESA countries' paved road length in 2009 , (\% of total road length) variable about infrastructure.

$\mathrm{X}_{5}=$ COMESA countries' mobile telephone subscriptions in 2009, (per 1000 persons) variable about infrastructure.

$\mathrm{X}_{6}=$ Dummy variable about political stability in COMESA countries, takes one where is apolitical stability and takes zero where is apolitical instability.

$\mathrm{X}_{7}=$ Dummy variable about landlocked countries in COMESA takes zero if the country is landlocked and one if the country isn't landlocked.

$\mathrm{X}_{8}=$ Dummy variable about sharing border, takes one if there is a sharing border between Egypt and COMESA country, and zero if there isn't.

Variables such as taxation and transportation cost were excluded as a result of lack of data. 


\section{Source of data}

Paper collected cross section data about variables defined in the model, data collected about year 2010 to 19 countries (COMESA member states) from the following reports:

- African Union (2012).

- World Bank (2013).

- COMESA, Annual Bulletin of Infrastructure Statistics (2011d).

\section{Model results}

Detailed results of the model are shown in statistical Additional file 1, paper concluded that the most effective variables that have the major effect on the value of exports of Egypt to COMESA countries were $\left(\mathrm{X}_{1}\right)$ Gross Domestic Product in COMESA countries and $\left(\mathrm{X}_{4}\right)$ which refers to the existence of sharing border between Egypt and COMESA countries. This means that each of Libya and Sudan are the most important export markets to Egypt because they have sharing border with it. Also Libya is more important than Sudan as an export market to Egypt, because it has the highest GDP and GDP per capita in COMESA. These results reflect the main obstacles that hindered deeper economic integration in COMESA such as poor condition of trade related infrastructure, the dependence on few primary commodities for export, the orientation towards extra regional trade, in addition to export identical products with low productivity.

\section{COMESA's International and intra- organizational trade}

Before analyzing the status of international and intra trade in COMESA region, it is important to represent some basic indicators about the economies of COMESA subregion as shown in the following Table 4.

During 2011, intra COMESA exports recorded $10.7 \%$ of its total exports, and intra COMESA imports were only $5.8 \%$ of its total imports, this means that economic integration especially trade relations with COMESA countries faces many obstacles referring to economic structure with these countries (Figure 2).

COMESA's growth performance in 2011 continued to be impressive compared to the world average with overall GDP increasing by $4.4 \%$ despite the lingering global financial crisis and the unfavorable political situation in Libya. This growth was driven by a number of factors particularly continued high demand for commodities.

\section{COMESA international trade}

One of the most important reasons that hindered the economic integration in COMESA is the orientation towards extra regional trade (particularly to EU, USA, and China) and export identical products with low productivity so it was necessary to analyze COMESA international trade and its effects on COMESA intra trade.

COMESA's total global trade declined by $8 \%$ from US\$ 257 billion in 2010 to US\$ 237 billion in 2011. Specifically, total exports dropped by $18 \%$ from levels of US\$ 115 billion in 2010 to US\$ 94 billion in 2011, as a result of the political instability circumstances faced by each of Egypt and Libya (the two major exporters in COMESA during 2011), while imports on the other hand registered a milder 1\% growth, from US\$ 142 billion in 2010 to US\$ 143 billion in 2011 (Figure 3). 
Table 4 COMESA in figures

\begin{tabular}{|c|c|c|c|c|c|c|c|c|c|c|}
\hline & \multirow[b]{2}{*}{$\begin{array}{l}\text { Member } \\
\text { state }\end{array}$} & \multirow[b]{2}{*}{$\begin{array}{l}\text { Total } \\
\text { area } \\
(\mathrm{km} 2)\end{array}$} & \multirow[b]{2}{*}{$\begin{array}{l}\text { Pop. } \\
\text { (M) } \\
2011\end{array}$} & \multirow[b]{2}{*}{$\begin{array}{l}\text { Density } \\
\text { per } \\
\text { km2 } \\
2011\end{array}$} & \multirow[b]{2}{*}{$\begin{array}{l}\text { Life } \\
\text { expec. } \\
2010\end{array}$} & \multirow[b]{2}{*}{$\begin{array}{l}\text { GDP } \\
\text { curr. } \\
\text { prices } \\
\text { US\$m } \\
2011\end{array}$} & \multicolumn{4}{|c|}{ Merchandise trade: US\$ Millions, 2011} \\
\hline & & & & & & & $\begin{array}{l}\text { Total } \\
\text { exports }\end{array}$ & $\begin{array}{l}\text { Total } \\
\text { imports }\end{array}$ & $\begin{array}{l}\text { Intra- } \\
\text { COMESA } \\
\text { exports }\end{array}$ & $\begin{array}{l}\text { Intra- } \\
\text { COMESA } \\
\text { imports }\end{array}$ \\
\hline 1 & Burundi & 27,830 & 8.58 & 308.1 & 50 & 2,326 & 197 & 858 & 38 & 158 \\
\hline 2 & Comoros & 1,861 & 0.75 & 405.1 & 61 & 610 & 24 & 201 & 3 & 7 \\
\hline 3 & Congo (D.R) & $2,344,860$ & 67.76 & 28.9 & 48 & 15,642 & 5,417 & 5,399 & 1,256 & 1,172 \\
\hline 4 & Djibouti & 23,200 & 0.91 & 39.0 & 58 & 1,049 & 1,532 & 1,591 & 1,037 & 115 \\
\hline 5 & Egypt & $1,001,450$ & 82.54 & 82.4 & 73 & 229,531 & 30,607 & 58,934 & 1,623 & 835 \\
\hline 6 & Eritrea & 117,600 & 5.42 & 46.0 & 61 & 2,609 & 309 & 480 & 10 & 95 \\
\hline 7 & Ethiopia & $1,104,300$ & 84.73 & 76.7 & 59 & 31,709 & 2,635 & 8,765 & 317 & 289 \\
\hline 8 & Kenya & 580,370 & 41.61 & 71.7 & 56 & 33,621 & 6,600 & 14,914 & 2,062 & 617 \\
\hline 9 & Libya & $1,759,540$ & 6.42 & 3.7 & 75 & 62,360 & 14,700 & 6,103 & 70 & 610 \\
\hline 10 & Madagascar & 587,040 & 21.32 & 36.3 & 66 & 9,947 & 1,456 & 2,904 & 50 & 174 \\
\hline 11 & Malawi & 118,480 & 15.38 & 129.8 & 53 & 5,700 & 1,410 & 2,423 & 312 & 226 \\
\hline 12 & Mauritius & 2,040 & 1.29 & 630.4 & 73 & 11,313 & 2,172 & 4,977 & 189 & 153 \\
\hline 13 & Rwanda & 26,340 & 10.94 & 415.4 & 55 & 6,377 & 418 & 1,359 & 151 & 368 \\
\hline 14 & Seychelles & 460 & 0.09 & 187.0 & 73 & 1,007 & 886 & 1,606 & 247 & 51 \\
\hline 15 & Sudan & $2,505,810$ & 34.32 & 13.7 & 61 & 55,097 & 8,981 & 9,546 & 423 & 661 \\
\hline 16 & Swaziland & 17,360 & 1.07 & 61.5 & 48 & 3,978 & 1,652 & 1,803 & 95 & 7 \\
\hline 17 & Uganda & 241,040 & 34.51 & 143.2 & 54 & 16,810 & 2,738 & 5,126 & 956 & 659 \\
\hline 18 & Zambia & 752,610 & 13.47 & 17.9 & 48 & 19,206 & 9,015 & 7,179 & 1,147 & 1,637 \\
\hline \multirow[t]{2}{*}{19} & Zimbabwe & 390,760 & 12.75 & 32.6 & 50 & 9,900 & 3,584 & 8,540 & 150 & 462 \\
\hline & COMESA & $11,602,951$ & 443.85 & - & - & 518,793 & 94,334 & 142,706 & 10,134 & 8,297 \\
\hline
\end{tabular}

Source: COMESA 2012, International Trade Statistics Bulletin, Lusaka: COMESA 39.

At the country level, all except Libya, Sudan and Swaziland registered positive growths in the levels of their global exports in 2011 over 2010 levels. On the import side, Libya, Sudan and Ethiopia recorded declines in levels of their global imports in 2011 over 2010 levels, in addition to political instability in Libya, Separation of Southern Sudan were the reasons of this depression. The rest of the COMESA countries

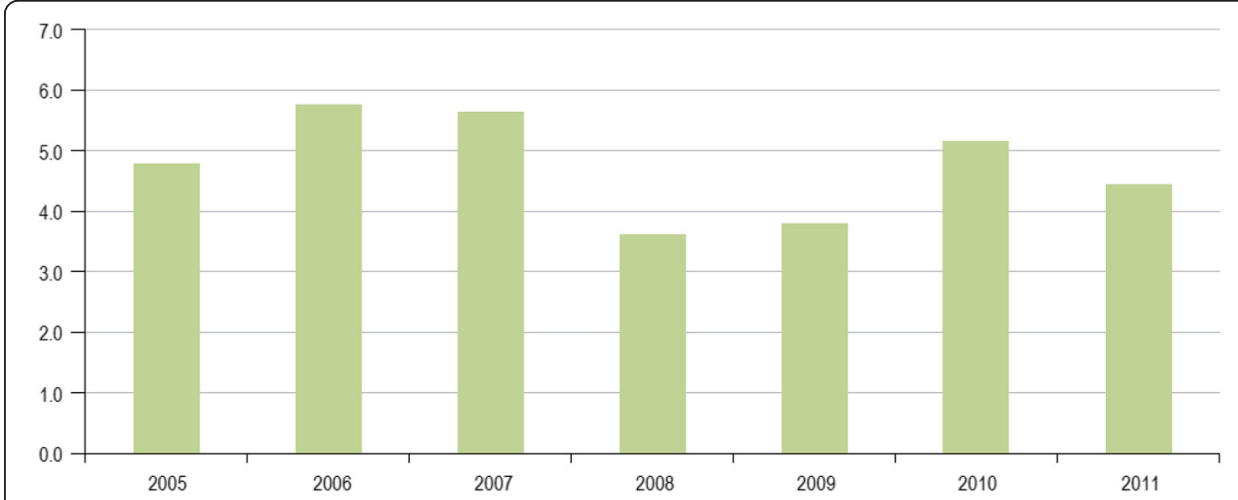

Figure 2 COMESA's GDP Growth (2005-2011). Source: COMESA 2012, International Trade Statistics

Bulletin, Lusaka: COMESA 6. 


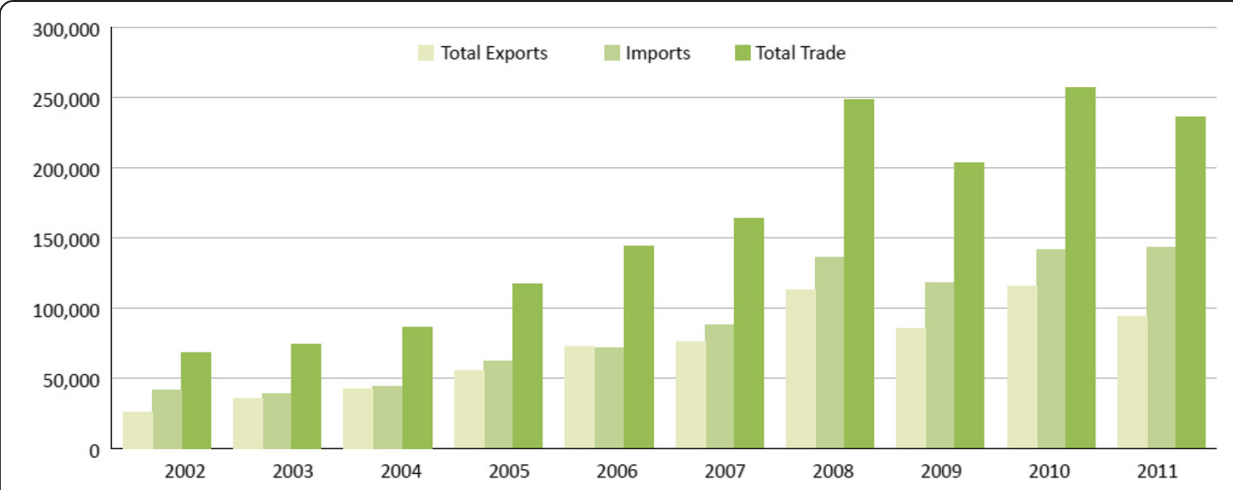

Figure 3 Global COMESA Trade (2002 - 2011). Values in US\$ millions. Source: COMESA 2012,

International Trade Statistics Bulletin, Lusaka: COMESA 6.

registered positive growths in levels of their imports. Table 5 below depicts global COMESA trade performance by country, for the period 2009 - 2011 and percentage change in 2011 (COMESA 2011a, b, c, d, e, f:25).

In 2011, only Libya (the major petroleum oils exporter in COMESA) registered favorable terms of trade (TOT) with the world, while the majority of the COMESA countries had unfavorable terms of trade with the world with ratios below 1 .

\section{COMESA's trade by product}

At the exports level each of fuels, food and agriculture raw materials, and ores and metals are the most important exports of COMESA.

\section{Exports of fuels}

Exports of fuels from the COMESA region accounting for 35\% of total exports in 2011. Exports in 2011 were worth a total of US\$ 33 billion. In 2011, Libya exported petroleum oils and oils obtained from bituminous minerals, both crude and preparations, worth over US\$ 13.1 billion mainly to Italy, France, China and Germany. Egyptian oil exports were worth over US\$ 6.5 billion in 2011. Sudan's exports of the same product in 2011 amounted to US\$ 7.4 billion and were mainly destined to China (COMESA 2012:17-20).

\section{Exports of ores and metals}

During the period under review, the region exported ores and metals worth over US\$ 14 billion, these exports accounted for $15 \%$ of the total exports as depicted in Figure 4 above. Major exporters of these ores and metals in the region are; Zambia and Democratic Republic of Congo for Copper; Sudan, Egypt, Zimbabwe and Ethiopia for Gold and both Zimbabwe and Egypt for Nickel. Exports of copper by Zambia, Africa's top producer, in 2011 were worth over US\$ 6.7 billion and these were mainly destined to Switzerland and China. The Democratic Republic of Congo exported copper, both refined and unrefined worth almost US \$ 2 billion in 2011, mainly to China and Zambia. Sudan's exports of gold in 2011 amounted to over US\$ 827 million mainly to the UAE and Canada while Egypt's exports of gold worth over US\$ 1.7 billion in 2011 were destined for South Africa, Lebanon, Switzerland and UAE. 
Table 5 Global COMESA trade by country, 2009 - 2011, values in US\$ millions

\begin{tabular}{|c|c|c|c|c|c|c|c|c|c|c|c|}
\hline \multirow{2}{*}{$\begin{array}{l}\text { Year } \\
\text { Country }\end{array}$} & \multicolumn{3}{|l|}{2009} & \multicolumn{3}{|l|}{2010} & \multicolumn{3}{|l|}{2011} & \multicolumn{2}{|c|}{ \% change (2011) } \\
\hline & Export & Re-export & Import & Export & Re-export & Import & Export & Re-export & Import & Total export & Import \\
\hline Burundi & 96 & 17 & 342 & 107 & 10 & 398 & 184 & 14 & 858 & 69.5 & 115.5 \\
\hline Comoros & 13 & - & 179 & 15 & 0 & 182 & 24 & & 201 & 65.3 & 10.7 \\
\hline Congo DR & 2,375 & - & 3,073 & 4,874 & & 4,526 & 5,417 & & 5,399 & 11.1 & 19.3 \\
\hline Djibouti & 157 & 206 & 647 & 299 & 699 & 1,402 & 462 & 1,069 & 1,591 & 53.4 & 13.5 \\
\hline Egypt & 23,110 & - & 44,964 & 26,665 & & 52,944 & 30,607 & & 58,934 & 14.8 & 11.3 \\
\hline Eritrea & 42 & 14 & 262 & 14 & & 457 & 309 & & 480 & $2,107.1$ & 5.1 \\
\hline Kenya & 4,201 & 813 & 11,388 & 5,088 & 768 & 12,021 & 5,761 & 839 & 14,914 & 12.7 & 24.1 \\
\hline Libya & 29,685 & - & 18,727 & 44,048 & & 21,500 & 14,700 & & 6,103 & -66.6 & -71.6 \\
\hline Madagascar & 1,015 & - & 2,565 & 924 & 115 & 2,279 & 1,360 & 96 & 2,904 & 40.1 & 27.4 \\
\hline Malawi & 1,291 & 3 & 1,754 & 1,048 & 1 & 2,344 & 1,404 & 6 & 2,423 & 34.5 & 3.3 \\
\hline Mauritius & 1,428 & 431 & 3,667 & 1,598 & 501 & 4,245 & 1,828 & 344 & 4,977 & 3.5 & 17.2 \\
\hline Rwanda & 189 & 23 & 1,258 & 202 & 35 & 1,255 & 371 & 47 & 1,359 & 75.8 & 8.3 \\
\hline Seychelles & 195 & 51 & 759 & 265 & 1 & 869 & 693 & 193 & 1,606 & 233.6 & 84.8 \\
\hline Sudan & 9,040 & 40 & 8,592 & 11,517 & 12 & 11,875 & 8,979 & 2 & 9,546 & -22.1 & -19.6 \\
\hline Swaziland & 1,305 & 92 & 1,069 & 1,579 & 119 & 1,739 & 1,594 & 58 & 1,803 & -2.7 & 3.7 \\
\hline Uganda & 1,381 & 450 & 4,307 & 1,105 & 427 & 4,550 & 2,199 & 539 & 5,126 & 78.7 & 12.7 \\
\hline Zambia & 4,095 & 212 & 3,792 & 6,834 & 338 & 5,022 & 8,644 & 372 & 7,179 & 25.7 & 43.0 \\
\hline Zimbabwe & 2,193 & 90 & 3,268 & 3,442 & 113 & 4,706 & 3,534 & 49 & 8,540 & 0.8 & 81.5 \\
\hline Total & 82,841 & 2,469 & 118,489 & 112,003 & 3,183 & 141,542 & 90,644 & 3,691 & 142,706 & (18.12) & 0.82 \\
\hline
\end{tabular}

Source: COMESA 2012, International Trade Statistics Bulletin, Lusaka: COMESA 7. 


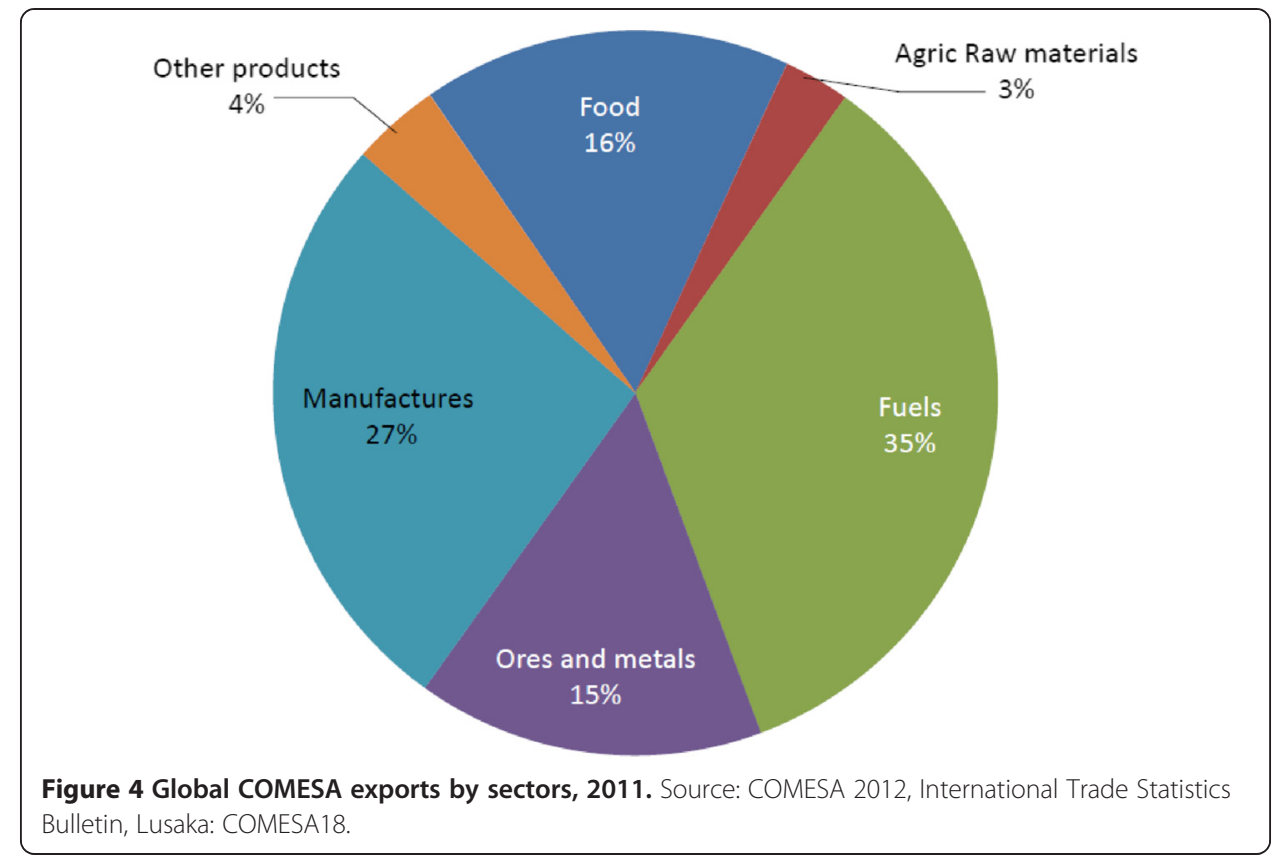

\section{Exports of food and agriculture raw materials}

Food exports value was US\$ 2.8 billion in 2011. Among key food export commodities in COMESA are tobacco, vegetables, fruits and nuts, tea and coffee. Notable exporters of vegetables and fruits in COMESA in 2011 were Egypt, Kenya, Ethiopia, Madagascar and Swaziland. Tobacco is exported mainly by Zimbabwe, Malawi, Kenya, Egypt and Zambia. In the beverage group, Ethiopia, Uganda and Kenya are the major exporters of coffee in the region, while tea is exported by Kenya, Malawi and Uganda.

From analyzing COMESA's structure of exports, paper concludes, that raw materials (fuels, food and agriculture, ores and metals) contain 69\% of its total exports in 2011 (more than two third of its total exports), this means that COMESA is more vulnerable to any shocks in prices and/or quantities demanded of these exports in international markets (COMESA 2012: 21-23).

At the imports level, each of manufactures, food, and fuels are the most important imports to COMESA.

\section{Imports of manufactures}

COMESA imports are dominated by manufactures and these accounted for $59 \%$ of the total imports in value terms for 2011. Within imports of manufactures, motor vehicles including those designed for the transport of persons, accounted for $4.4 \%$ of total sector imports followed by fertilizers which accounted for $4.2 \%$ of manufactures imports (Figure 5).

\section{Imports of food}

Imports of food products in the COMESA region increased overall by $13 \%$, from US\$ 24.1 billion in 2010 to US\$27.2 billion in 2011. The increase in food imports can be mainly attributed to the increase in maize imports of 52\% between 2010 and 2011 


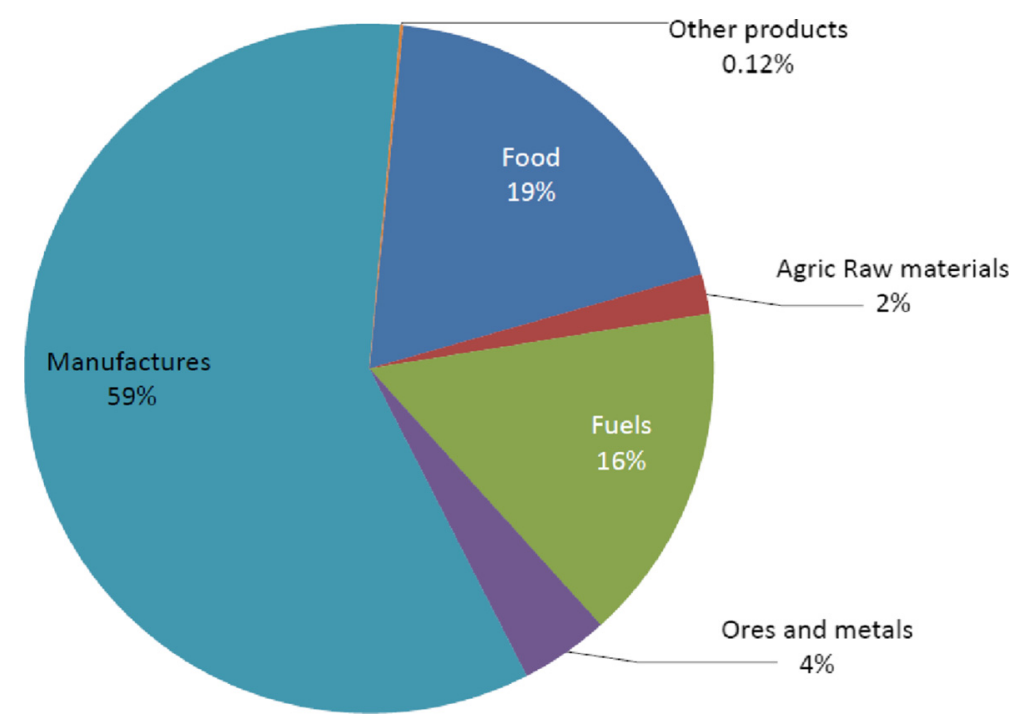

Figure 5 Global COMESA imports by sectors (2011). Source: COMESA 2012, International Trade Statistics Bulletin, Lusaka: COMESA 21.

(COMESA 2011a, b, c, d, e, f:19-20). Increases in COMESA's food imports bill can also refers to increases in global food prices during food crisis started in the second half of 2006, where world prices of most major food commodities began to climb. By the first half of 2008, international (US Dollar) prices of cereals had reached their highest levels in almost 30 years, threatening the food security of the poor worldwide and provoking wide spread international concern over an apparent world crisis (Food and Agriculture Organization FAO 2009:4). Food prices were up as much as 40\% from their 2007 level and 76\% from 2006 (Food and Agriculture Organization FAO 2009:6).

\section{Intra- COMESA trade}

Referring to Table 3, COMESA intra exports represent $10.7 \%$ of total exports and intra imports represent only $5.8 \%$ of total imports during 2011. Table 6 below shows intraCOMESA trade as a percentage of total trade during (2003-2011), it seems that intra trade of COMESA is very weak ranging about $5 \%$ and $8 \%$ as a result of the dependence of COMESA economies on a few primary commodities for exports, and their oriented towards extra regional trade particularly to EU and China. Furthermore, intra COMESA trade is hindered by a lack of infrastructure particularly in the area of transport and communications, non- tariffs barriers, and social and political tensions in several countries of the region.

Intra-COMESA trade grew by $6 \%$ in 2011 up from US\$ 17.3 billion in 2010 to US\$ 18.4 billion in 2011. Major contributors to this growth were Kenya, Zambia, Burundi, Mauritius and Uganda. Figure 6 below depicts the performance of intra-COMESA trade over the period $2002-2011$.

As far as COMESA export market shares are concerned, Kenya had the largest market share of $20 \%$ for intra COMESA exports. Kenya was followed by Egypt, Congo DR and Zambia with shares of $16 \%, 12 \%$ and $11 \%$ respectively, because these countries are the major exporters of fuels, agriculture raw materials and ores and metals. 
Table 6 Intra-COMESA trade as a percentage of total COMESA trade (2003-2011)

\begin{tabular}{|c|c|c|c|c|c|c|c|c|c|}
\hline Country & 2003 & 2004 & 2005 & 2006 & 2007 & 2008 & 2009 & 2010 & 2011 \\
\hline Burundi & 22 & 21 & 18 & 17 & 26 & 22 & 26 & 25 & 19 \\
\hline Comoros & 3 & 4 & 3 & 9 & 3 & 5 & 5 & 8 & 5 \\
\hline Congo DR & 16 & 13 & 8 & 12 & 18 & 17 & 22 & 21 & 22 \\
\hline Djibouti & 14 & 6 & 9 & 1 & 8 & 4 & 18 & 28 & 37 \\
\hline Egypt & 3 & 2 & 2 & 2 & 2 & 4 & 4 & 4 & 3 \\
\hline Eritrea & 3 & 1 & 9 & 13 & 5 & 13 & 17 & 33 & 13 \\
\hline Ethiopia & 6 & 4 & 6 & 8 & 5 & 5 & 4 & 5 & 5 \\
\hline Kenya & 15 & 16 & 16 & 12 & 11 & 11 & 11 & 12 & 12 \\
\hline Libya & 1 & 0 & 1 & 1 & 1 & 2 & 3 & 3 & 3 \\
\hline Madagascar & 4 & 5 & 6 & 4 & 5 & 3 & 5 & 7 & 5 \\
\hline Malawi & 13 & 13 & 14 & 13 & 15 & 9 & 10 & 13 & 14 \\
\hline Mauritius & 5 & 4 & 4 & 4 & 5 & 5 & 5 & 4 & 5 \\
\hline Rwanda & 24 & 25 & 32 & 48 & 38 & 40 & 37 & 33 & 29 \\
\hline Seychelles & 2 & 4 & 2 & 2 & 3 & 4 & 6 & 4 & 12 \\
\hline Sudan & 10 & 7 & 5 & 5 & 5 & 4 & 4 & 5 & 6 \\
\hline Swaziland & 4 & 3 & 2 & 5 & 9 & 9 & 6 & 4 & 3 \\
\hline Uganda & 25 & 25 & 28 & 20 & 22 & 20 & 21 & 21 & 21 \\
\hline Zambia & 15 & 13 & 13 & 9 & 12 & 16 & 16 & 17 & 17 \\
\hline Zimbabwe & 3 & 6 & 13 & 5 & 10 & 7 & 6 & 7 & 5 \\
\hline COMESA & 6 & 5 & 5 & 5 & 6 & 6 & 6 & 7 & 8 \\
\hline
\end{tabular}

Source: COMESA 2012, International Trade Statistics Bulletin, Lusaka: COMESA 38.

On the import side, Zambia still registered the biggest market share of $20 \%$ in 2011, Zambia was followed by Congo DR in second position with an intra-import market share of $14 \%$. Egypt and Sudan ranked in third and fourth positions with shares of $10.1 \%$ and $8 \%$ respectively, because these countries are the major importers of manufactures and food (COMESA 2012:35-38) (Table 7).

Overall, Copper ores and concentrates continued to be the top most exported products in value terms within the COMESA region in 2011. Ranked second after the Copper ores and concentrates was black tea. Portland cement and refined copper were ranked in the third and fourth positions respectively in 2011. The percentage of intraCOMESA trade to total COMESA trade increased marginally from $7 \%$ to $8 \%$ in 2011 (COMESA 2012:35-38).

\section{Egypt Trade with COMESA Countries}

Egypt has joined to COMESA since May 1998, according to COMESA data base (2011) Egypt exports to COMESA countries recorded 5\% of its total exports, and Egypt's imports from COMESA countries recorded only $1.5 \%$ of its total imports, only $3 \%$ from Egypt trade occurs with COMESA, so that Egypt trade with COMESA faces many obstacles, therefore, it is important to analyze Egypt trade with COMESA countries as follows.

Value of Egypt trade with COMESA

According to COMESA data base, during 2011 Egypt total exports were 30,607 US\$ billion, imports were 58,934 US\$ billion and the Figure 7 below shows value of Egypt's 


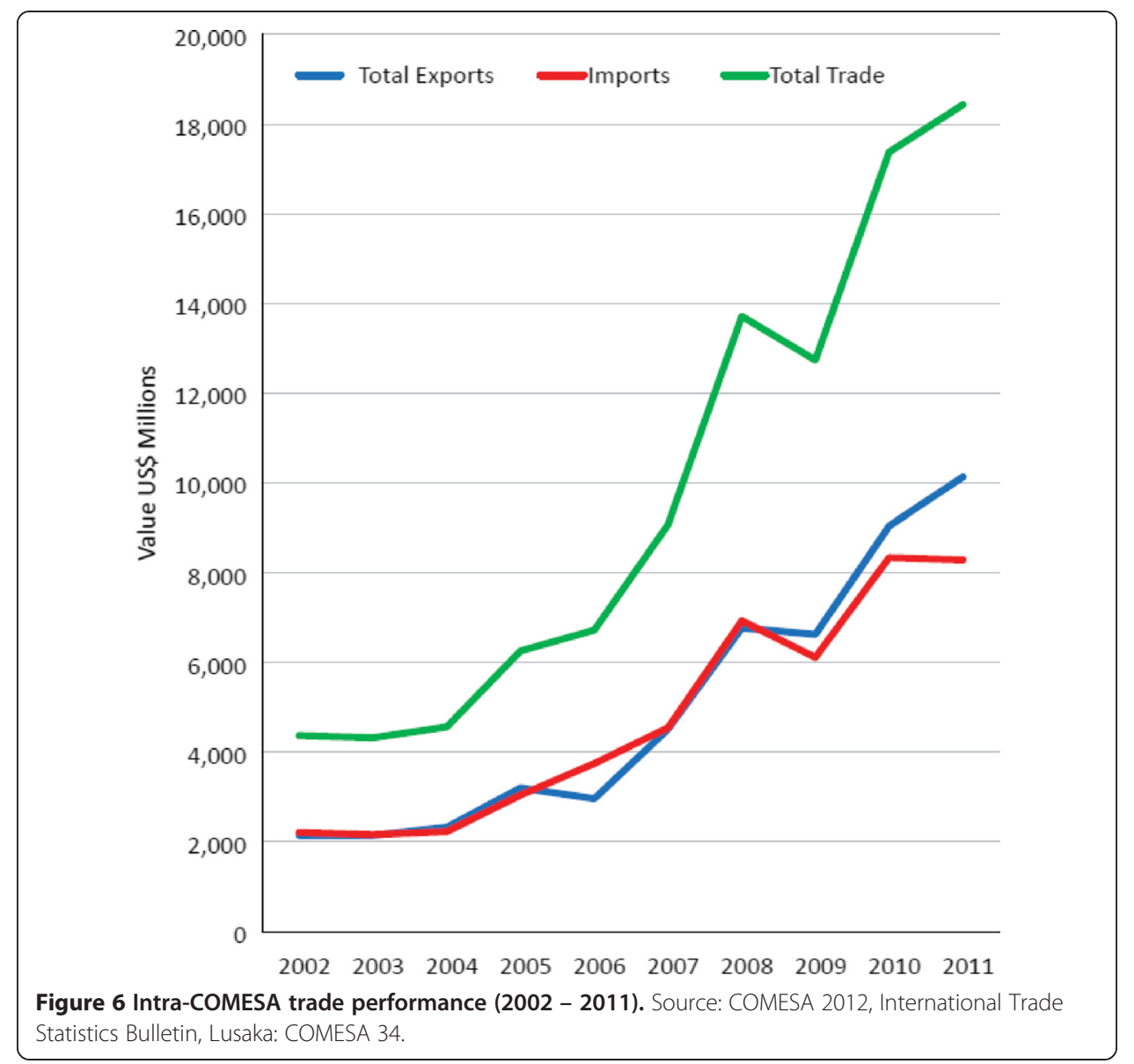

total exports, imports and trade balance with COMESA during (2002-2011). Figure 7 shows that, except year 2002 Egypt trade balance with COMESA recorded an increasing surplus, but value of this surplus declined in 2011 as a result of political instability circumstances occurred in Egypt (COMESA 2011a, b, c, d, e, f:2-3).

On the other hand, Figure 8 below shows Egypt's extra COMESA trade during the same period (2002-2011), it is clear that Egypt trade balance with the rest of the world achieved deficit during the same period. During (2006-2011) Egypt's extra COMESA export trading partners were EU, India, and Saudi Arabia respectively. While, EU, USA, and China were Egypt's extra COMESA import trading partners during the same period.

\section{Egypt trade partners in COMESA}

\section{Export markets}

Table 8 and Figure 9 below shows major trade partners to Egypt among COMESA countries in field of exports. It seems that Libya (34\%, because it has the highest GDP and GDP per capita in COMESA and it has sharing border with Egypt), Sudan (31\%, because it has sharing border with Egypt) and Kenya (13\%, Kenya is an important market of Egyptian manufactures) are the most important export partners in 2011 respectively, because each of Libya and Sudan has sharing borders with Egypt and Kenya imports manufactures from Egypt. 
Table 7 Intra-COMESA trade, 2011, values in US\$ millions and \% shares

\begin{tabular}{lllllll}
\hline No & Exporter & Total exp & \% Share & Importer & Imports & \% share \\
\hline 1 & Kenya & $2,061.5$ & 20.3 & Zambia & $1,636.6$ & 19.7 \\
2 & Egypt & $1,622.5$ & 16.0 & Congo DR & $1,172.0$ & 14.1 \\
3 & Congo DR & $1,256.0$ & 12.4 & Egypt & 834.8 & 10.1 \\
4 & Zambia & $1,146.7$ & 11.3 & Sudan & 661.2 & 8.0 \\
5 & Djibouti & $1,036.7$ & 10.2 & Uganda & 659.5 & 7.9 \\
6 & Uganda & 955.7 & 9.4 & Kenya & 617.5 & 7.4 \\
7 & Sudan & 422.9 & 4.2 & Libya & 609.9 & 7.4 \\
8 & Ethiopia & 316.8 & 3.1 & Zimbabwe & 462.0 & 5.6 \\
9 & Malawi & 312.4 & 3.1 & Rwanda & 368.0 & 4.4 \\
10 & Seychelles & 247.2 & 2.4 & Ethiopia & 289.4 & 3.5 \\
11 & Mauritius & 188.7 & 1.9 & Malawi & 225.6 & 2.7 \\
12 & Rwanda & 151.4 & 1.5 & Madagascar & 174.3 & 2.1 \\
13 & Zimbabwe & 150.5 & 1.5 & Burundi & 157.7 & 1.9 \\
14 & Swaziland & 94.6 & 0.9 & Mauritius & 152.9 & 1.8 \\
15 & Libya & 70.0 & 0.7 & Djibouti & 115.0 & 1.4 \\
16 & Madagascar & 50.1 & 0.5 & Eritrea & 94.6 & 1.1 \\
17 & Burundi & 37.8 & 0.4 & Seychelles & 51.2 & 0.6 \\
18 & Eritrea & 10.0 & 0.1 & Comoros & 7.5 & 0.1 \\
19 & Comoros & 2.8 & 0.0 & Swaziland & 7.0 & 0.1 \\
& Total & $10,134.3$ & 100.0 & & $8,296.8$ & 100.0 \\
\hline Source & COMA 2012, & & & & \\
\hline
\end{tabular}

Source: COMESA 2012, International Trade Statistics Bulletin, Lusaka: COMESA 36.

\section{Import markets}

Table 9 and Figure 10 below shows Egypt's top COMESA import trading partners during (2005-2011). It seems that Zambia (37.9\%), Kenya (37.5\%) and Malawi (8.6\%) are top import trading partners in COMESA in 2011 respectively because these countries are an important source of agriculture raw materials (COMESA 2011a, b, c, d, e, f:2-4).

\section{Structure of Egypt's exports and imports with COMESA Countries}

Manufactures exports are highly important even that oriented to COMESA or to the rest of the world. Table 10 below shows structure of exports of Egypt with COMESA countries and its structure of export with the world. It seems that the most important export of Egypt to COMESA is manufactures good (57.2\%) then exports of food (31.5\%) in 2011.

\section{The Obstacles to Regional Integration in COMESA and How to Overcoming it?}

Poor intra- COMESA trade performance can be explained by several limiting factors. Barriers to intra- community trade development are numerous and are rooted in the economic structures of countries in question; institutional, infrastructural and financial constraints.

Before discussion of these factors, it is necessary to indicate to political instability circumstances that hindered the performance of Egyptian economy after the $25^{\text {th }}$ January Revolution. Few observers would have predicted the dramatic change over the past few years in Egypt, government appeared to be in tight control, annual growth rate averaged more than $6 \%$ between 2005 and 2010 but there is strong indication that growth 


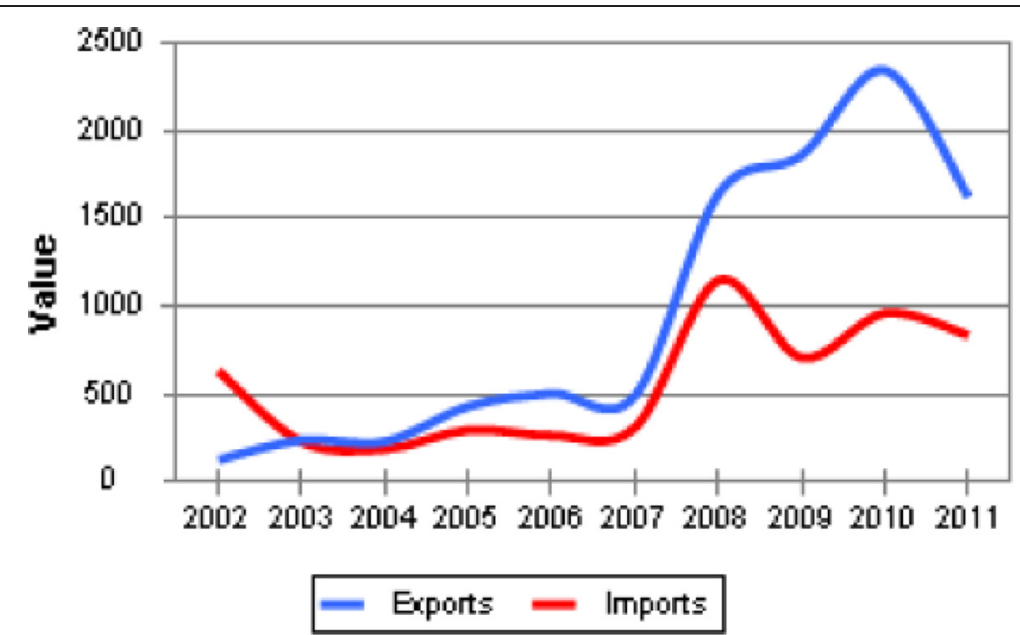

Figure 7 Egypt Trade with COMESA US\$ millions. Source: COMESA 2011a, b, c, d, e, f, Egypt Trade Statistics Profile, Lusaka: COMESA 2.

in GDP has not trickled down to the people and that rising inequalities. In Egypt, civil disturbance early 2011 has already affected export and investment sectors and the performance of the overall economy (Breisinger et al. 2012:1-2).

\section{Constraints linked to economic structures}

The economics of COMESA countries are characterized by their dependence on a few primary commodities for export. Furthermore, the countries of a single region export similar product; this significantly reduces the potential for sub-regional trade on large scale. As a result, these countries are more oriented towards extra- regional trade, particularly to EU, America and China which remain their primary trade partners.

Manufacturing production remains marginal and, in many cases, cannot meet local demand. Furthermore, COMESA countries tend to export identical products which are, to a large extent, aimed at the industrialized countries that are the main customers for

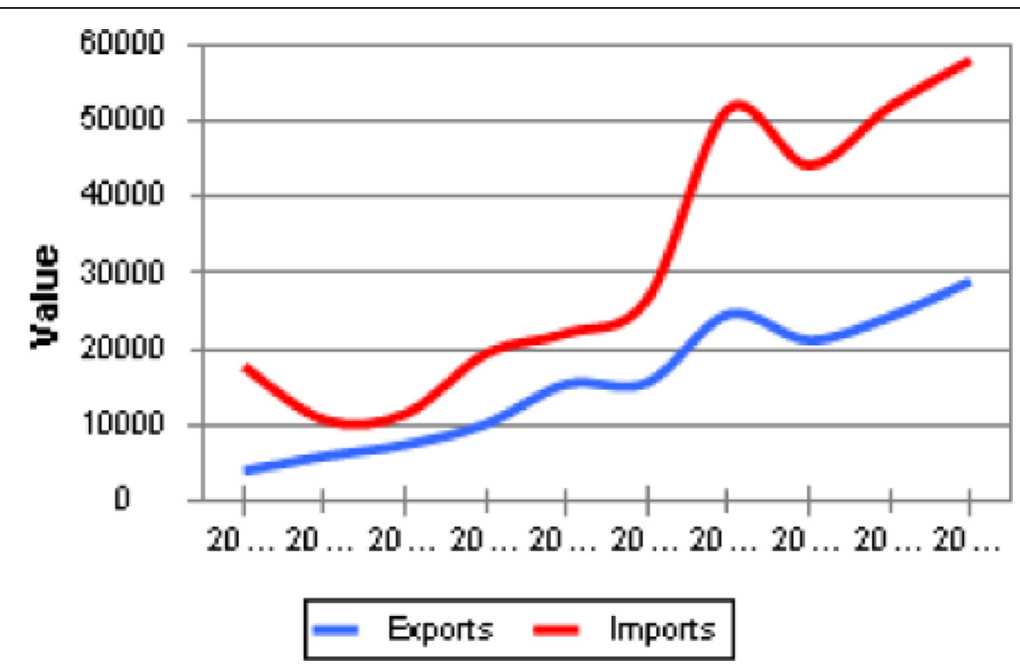

Figure 8 Egypt extra- COMESA trade US\$ millions. Source: COMESA $2011 \mathrm{a}, \mathrm{b}, \mathrm{c}, \mathrm{d}$, e, f, Egypt Trade Statistics Profile, Lusaka: COMESA 2. 
Table 8 Egypt top COMESA export trading partners (2005-2011) value in US\$ millions

\begin{tabular}{lllllllll}
\hline Partner & & Year & \multicolumn{7}{l}{} \\
\cline { 3 - 8 } & $\mathbf{2 0 0 5}$ & $\mathbf{2 0 0 6}$ & $\mathbf{2 0 0 7}$ & $\mathbf{2 0 0 8}$ & $\mathbf{2 0 0 9}$ & $\mathbf{2 0 1 0}$ & $\mathbf{2 0 1 1}$ \\
\hline 1 & Libya & 149.47 & 187.87 & 232.34 & 808.73 & 985.02 & 1249.28 & 553.08 \\
2 & Sudan & 184.39 & 220.42 & 152.14 & 547.24 & 563.55 & 586.18 & 510.45 \\
3 & Kenya & 49.81 & 56.87 & 69.40 & 114.81 & 113.98 & 239.84 & 225.64 \\
4 & Eritrea & - & - & - & 14.57 & 33.01 & 57.87 & 61.33 \\
5 & Uganda & 2.76 & 4.43 & 5.78 & 19.64 & 21.21 & 24.73 & 59.77 \\
6 & Djibouti & 8.37 & 4.91 & 4.60 & 21.54 & 27.91 & 28.79 & 44.14 \\
7 & Ethiopia & 22.23 & 14.97 & 10.05 & 65.22 & 38.30 & 47.21 & 43.78 \\
8 & Zambia & 1.46 & 0.94 & 1.96 & 7.62 & 6.78 & 12.05 & 32.02 \\
9 & Mauritius & 5.60 & 6.14 & 11.62 & 17.06 & 21.25 & 26.76 & 31.57 \\
10 & Congo DR & 0.48 & 1.86 & 1.61 & 7.00 & 21.09 & 20.62 & 16.93 \\
\hline
\end{tabular}

Source: COMESA 2011a, b, c, d, e, f, Egypt Trade Statistics Profile, Lusaka: COMESA 3.

such products. Owing to a lack of appropriate industries, primary commodities are not processed in COMESA countries, which import most manufactured products such as medicine, food products and cotton-based textiles.

The low capacity of the manufacturing sector and the lack of diversified production reduce the capacities of COMESA members in terms of the production of raw materials, capital goods and intermediary processes within their trading blocs; this forces them to depend on external sources. In addition, the untapped energy potential in some sub regions makes it impossible to produce enough energy to support the manufacturing sector or businesses with a high added value.

One of the primary obstacles to the development of trade in COMESA lies in the similar goods production structures of COMESA countries; most of them supply virtually the same agricultural commodities, although their most pressing needs are for manufactured goods an area in which the developed countries with market economies have an undeniable advantage (Karingi et al. 2006:17-18).

\section{Constraints linked to infrastructures}

Intra COMESA trade is thus hindered by a lack of infrastructure, particularly in the area of transport and communications. The road network consists mainly of unpaved roads which are unusable for part of the year. COMESA entrepreneurs are, therefore handicapped by inadequate physical infrastructures and by lack of telecommunications. Furthermore, Governments themselves have made transport problems worse by instituting costly trade procedures that require the processing of customs documents (Economic Commission for Africa ECA, 2013a, b:102).

\section{Constraints linked to the institutional framework}

\section{Failure to apply laws at expanding intra- COMESA trade}

The absence of regulatory or punitive measures for cases of non-application of community law may account for the failure to apply the provisions of laws relating to development of intra- COMESA trade development. (UNCTAD 2011, 71). In addition to this, majority of COMESA countries are joined to other regional communities and therefore 


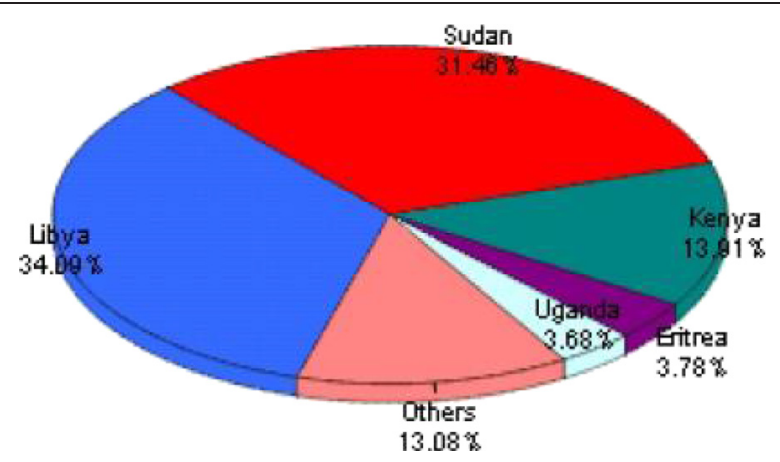

Figure 9 Egypt top COMESA export markets (2005-2011). Source: COMESA 2011a, b, c, d, e, f, Egypt Trade Statistics Profile, Lusaka: COMESA 3.

became unable to apply the regulation of each community as shown in the Figure 11 below:

1- Non- tariff barriers

It should be stressed that many COMESA states still apply a number of protectionist measures which pose obstacles to the promotion of intra- community trade. These measures include numerous road blocks and customs posts between countries, despite the resolutions adopted with a view to ensuring the free movement of goods and persons.

The existence of these checkpoints, and harassment at border points, hinder the normal course of transactions and, in particular, the cross-border transport of goods. Restrictions on the free movement of persons and inputs, restrictions on cross-border investments and poor bank and other financial lending also have an impact on trade and productivity.

Other barriers are posed by complicated import and export procedures, protectionist measures for local industries, enacted in order to compensate for the loss of customs revenue for all imported products, and the lack of measures to support intra-regional trade.

Table 9 Egypt's top COMESA import trading partners (2005-2011) value in US\$ millions

\begin{tabular}{lllllllll}
\hline Partner & & Year & \multicolumn{7}{l}{ Y008 } & $\mathbf{2 0 0 9}$ & $\mathbf{2 0 1 0}$ & $\mathbf{2 0 1 1}$ \\
\cline { 3 - 8 } & & $\mathbf{2 0 0 5}$ & $\mathbf{2 0 0 6}$ & $\mathbf{2 0 0 7}$ & $\mathbf{2 0 0}$ \\
\hline 1 & Zambia & 62.65 & 23.43 & 19.67 & 598.78 & 194.53 & 260.10 & 316.92 \\
3 & Kenya & 3.87 & 2.30 & 10.74 & 201.02 & 207.91 & 206.59 & 313.47 \\
4 & Libya & 119.22 & 112.85 & 164.80 & 261.34 & 211.82 & 335.68 & 60.25 \\
5 & Malawi & 24.31 & 19.30 & 31.46 & 1.69 & 16.86 & 39.17 & 55.87 \\
6 & Djibouti & 1.30 & 9.25 & 5.93 & 13.93 & 15.66 & 43.39 & 29.78 \\
7 & Sudan & 64.67 & 66.07 & 49.87 & 48.79 & 43.66 & 41.76 & 26.68 \\
8 & Ethiopia & 12.34 & 29.88 & 15.71 & 12.12 & 7.93 & 10.63 & 20.32 \\
9 & Uganda & 1.45 & 1.30 & 12.41 & 5.47 & 4.75 & 2.07 & 5.76 \\
10 & Mauritius & - & 0.04 & 0.09 & 0.32 & 0.43 & 0.96 & 2.22 \\
\hline
\end{tabular}

Source: COMESA 2011a, b, c, d, e, f, Egypt Trade Statistics Profile, Lusaka: COMESA 3. 


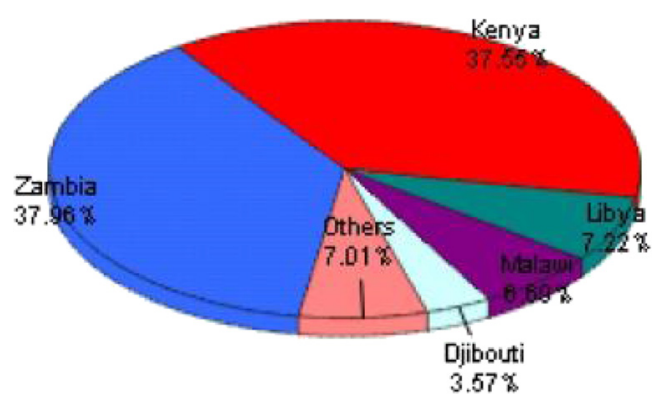

Figure 10 Egypt's top COMESA import trading partners (2005-2011). Source: COMESA 2011 a, b, c, d, e, f, Egypt Trade Statistics Profile, Lusaka: COMESA 3.

In conclusion, the persistence of non-tariff barriers which some States attempt to justify may slow the development of intra-Community trade. This situation, which is contrary to the customs union and common market spirit, should be remedied.

2- Payment and insurance problems:

COMESA countries' economies have no real foreign trade financing mechanisms adapted to the needs of the exporting firms. Even traditional mechanisms based on bank financing, have major limitations in this area.

3- Social and political tensions:

The social and Political tensions in which several countries have been mired for decades have also affected the performance and prospects of countries concerned of the economic integration area. Social and economic unrest also tends to discourage investment. Furthermore, the social and political tensions in which several sub regions have been mired for decades have also affected the performance and prospects of the countries concerned and of the economic integration area. These events have resulted in widespread destruction of production facilities, breakdown of national administrations, urban unemployment and capital flight. Social and economic unrest also tends to discourage investment and, generally speaking, creates an unviable macroeconomic framework by encouraging foreign investors' fear that it will spread to neighboring countries. (Metzger 2008:66-69)

\section{Measures and mechanisms in support of trade in COMESA (Some Policy Implications)}

In order to promote trade liberalization and expand COMESA intra-regional trade, it is important that, in tandem with the implementation of trade liberalization programmes by the COMESA, greater attention should be paid to some of the major issues that could be addressed with a view to more rapid achievement of the goal of market integration for COMESA. These include creation of an enabling political and economic climate for private investment within each COMESA, private sector participation in the integration process, and linking the member States of each COMESA to adequate transport and communication infrastructures. (Spence and Karingi 2011,75)

\section{1- Stable macroeconomic environment}

To promote sustained economic growth and improved living standards by creating a stable economic environment for entrepreneurs. (Dupasquier and Dsakwa

2006,53) 
Table 10 Structure of Egypt's exports to COMESA and World (2011) value in US\$ million and $\%$

\begin{tabular}{|c|c|c|c|c|}
\hline \multirow{2}{*}{$\begin{array}{l}\text { Exports to } \\
\text { Export of }\end{array}$} & \multicolumn{2}{|c|}{ COMESA } & \multicolumn{2}{|l|}{ World } \\
\hline & Value & $\%$ of exports to COMESA & Value & $\%$ of exports to world \\
\hline Food & 511.61 & 31.5 & 4075.74 & 13.3 \\
\hline Agriculture raw materials & 6.98 & 4.3 & 461.95 & 1.5 \\
\hline Fuel & 26.95 & 1.6 & 9164.91 & 29.9 \\
\hline Ores and metals & 74.56 & 4.6 & 1726.63 & 5.6 \\
\hline Manufactures & 928.46 & 57.2 & 12349.39 & 40.3 \\
\hline Others & 76.25 & 4.7 & 2877.0 & 9.4 \\
\hline Total & 1622.5 & 100 & 30607.39 & 100 \\
\hline
\end{tabular}

Source: COMESA Database.

2- Promote diversification and specialization in COMESA

By encouraging the production of non-traditional export commodities with a competitive advantage on regional and global markets, in addition each country should specialize in products which offer comparative advantages over other countries of the region. This will sever to open up trade opportunities between them.

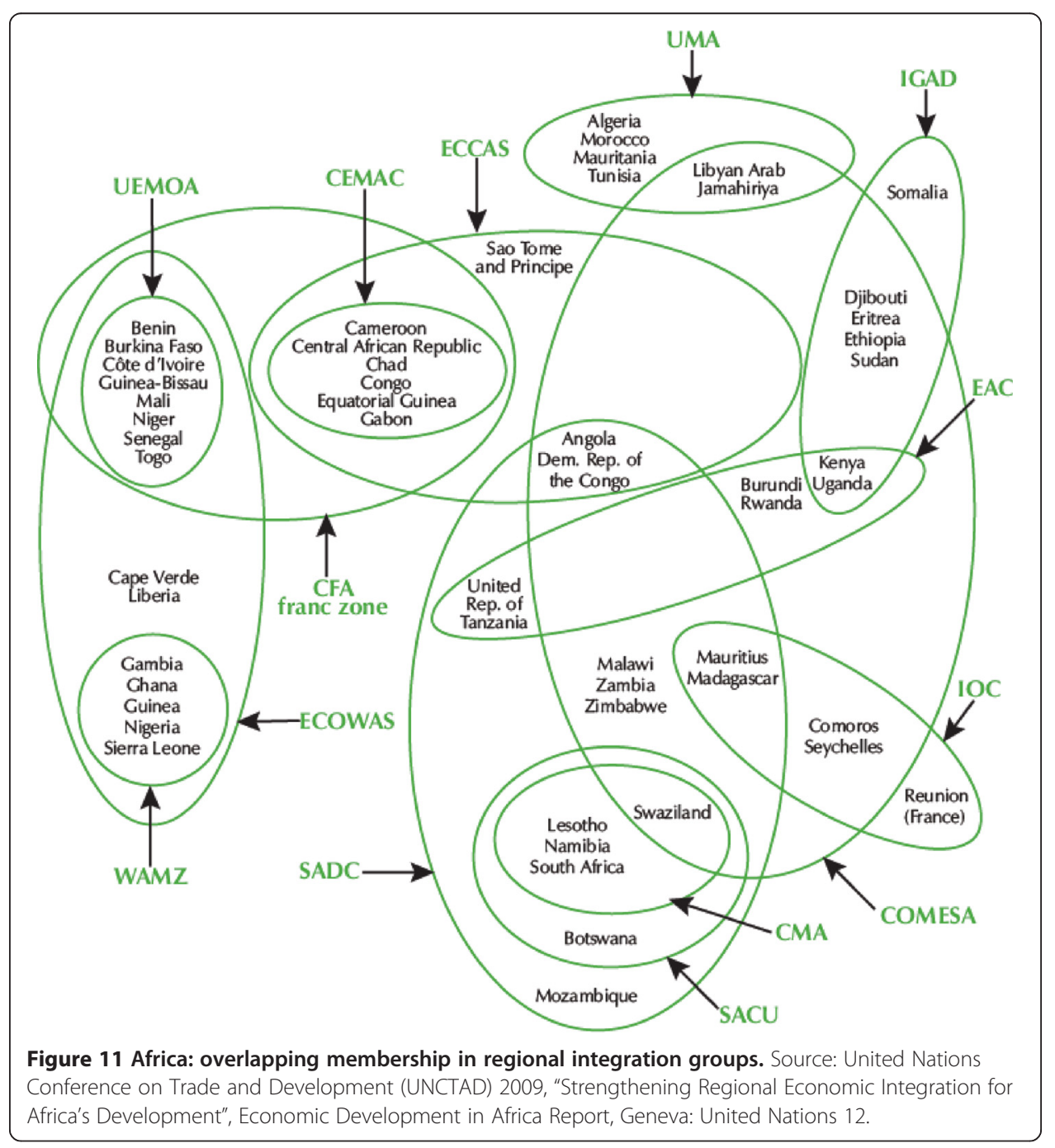


3- Assistance and support in the areas of quality control and standards information.

4- Rationalization of the institutional framework: To more competent structures with the necessary technical, human and financial technical abilities.

5- Human resource promotion: To develop the capacities needed in the implementation of trade liberalization for local products.

6- Improvement of physical infrastructures of the sub-regional level. Considerable progress should be done to improve infrastructure in order to facilitate trade and labour mobility, integrate markets and reduce the cost of trade transactions.

7- Investment promotion and facilitation of payment systems.

8- The free movement of goods and persons.(Abdoulahi 2005,29-40)

\section{The findings}

There are two major motivations for formation of trade blocs, allocation and accumulation effect of free trade with a regional block. COMESA has achieved some progress in areas of free movement of persons, physical integration, energy, information and communication technologies. According to COMESA structure of exports, which highly dominated by raw materials, COMESA is more vulnerable to shocks in international markets, Especially EU and China (COMESA's major trade partners).

COMESA intra- trade is very weak, in 2011 intra trade was $8 \%$ of total (intra exports was $11 \%$ of total, intra imports was $5 \%$ of total). Egypt's exports to COMESA recorded $5 \%$ of its total exports; and imports to COMESA recorded 1.5\% of its total imports during 2011 also.

Estimation of Egypt Trade Intensity Index with COMESA refers to opportunities to increase trade Intensity in the future, while applying gravity model, results in Goss Domestic product in COMESA countries and existence of sharing borders with Egypt and COMESA countries are the most important variables determine Egypt trade with COMESA.

There are economic, institutional, social, political and infra-structural obstacles hindered regional economic integration in COMESA, Promote diversification and specialization Improvement of physical infrastructures, and Investment promotion and facilitation of payment systems are some Mechanisms in support of regional integration in COMESA.

\section{Conclusion}

This paper has examined Determinants of Trade Intensity of Egypt with COMESA Countries (gravity model approach), model suggest a potential for Egypt- COMESA trade, Realizing this potential and hence the effort to advance regional integration through intra-COMESA trade is challenged by the similarity of exports and imports and the relative competitive position of COMESA suppliers. This is the result of weak infrastructural basis, weak productivity and weak trade facilitation.

This calls for a new and different approach to enhancing intra-COMESA trade and furthering regional integration. The issue is fundamentally about addressing supply constraints and the competitiveness of COMESA exports and their diversification.

Regional integration schemes should address these challenges through regulatory policies that foster integration and intra-COMESA trade, Regional integration schemes should also address multi-country infrastructure and policy coordination. With respect to trade facilitation, efficient core services such as finance, telecommunication, energy and transportation must be fostered. 


\section{Additional file}

Additional file 1: Annex: Gravity Model Results.

\section{Competing interests}

The authors declare that they have no competing interests.

Received: 10 November 2014 Accepted: 10 November 2014

Published online: 05 February 2015

\section{References}

Abdoulahi, Mohamat. 2005. "Progress Report on Regional Integration Efforts in Africa toward the Promotion of IntraAfrica Trade", Africa Trade Policy Centre (ATPC), Work in Progress (30). Addis Ababa: ATPC.

African Union. 2012. Status of Intra- Africa Trade. Addis Ababa: African Union.

African Union Commission. 2013. Status of Integration in Africa. Addis Ababa: African Union.

Breisinger, Clemens, Olivier Ecker, Perrihan Al-Riffai, and Xu Bingxin. 2012. "Beyond the Arab Awakening: Policies and Investments for Poverty Reduction and Food Security", Food Policy Report. Washington D.C: IFPRI.

COMESA. 2000. COMESA Treaty. Lusaka: COMESA.

COMESA. 2010. "New Release- Interim HCPI- COMESA", COMESA Macroeconomic Indicators. Lusaka: COMESA. Issue (20).

COMESA. 2011 a. "Making the CBTA Sustainable", Cross Border Trade Bulletin (3). Lusaka: COMESA.

COMESA. 2011b. "The COMESA Common Investment Area- Creating an Enabling Investment Environment", COMESA Investment Report. Lusaka: COMESA.

COMESA. 2011c. Aid for Trade Strategy 2012-2015. Lusaka: COMESA.

COMESA. 2011d. Annual Bulletin of Infra Structure Statistics. Lusaka: COMESA.

COMESA. 2011e. COMESA Investment Report. Lusaka: COMESA.

COMESA. 2011 f. Egypt Trade Statistics Profile. Lusaka: COMESA.

COMESA. 2012. International Trade Statistics Bulletin. Lusaka: COMESA

COMESA Administrator. 2000. COMESA's Priorities and Objectives. Lusaka: COMESA.

COMESA Administrator. 2003. Looking Back Evaluation of PTA/ COMESA. Lusaka: COMESA.

Dupasquier, Chantal, and Partick N Dsakwa. 2004. "Economic and Statistical Analyses of Trade Capacity Building in subSaharan Africa", African Trade Policy Centre (ATPC), Work in Progress (9). Addis Ababa: ATPC.

Dupasquier, Chantal, and Partick N Dsakwa. 2006. "Trade Regimes Liberalization and Macroeconomic Instability in Africa", African Trade Policy Centre (ATPC) Work in Progress (31). Addis Ababa: ATPC.

Economic Commission for Africa (ECA). 2004. Assessing Regional Integration in Africa. Addis Ababa: ECA.

Economic Commission for Africa (ECA). 2008. "Towards Monetary and Financials Integration in Africa", Assessing Regional Integration in Africa III. Addis Ababa: ECA.

Economic Commission for Africa (ECA). 2010. "Enhancing intra- African Trade, Assessing Regional Integration in Africa IV. Addis Ababa: ECA.

Economic Commission for Africa (ECA). 2012. "Towards an African Continental Free Trade Area", Assessing Regional Integration in Africa V. Addis Ababa: ECA.

Economic Commission for Africa (ECA). 2013a. "Harmonizing Policies to Transform the Trading Environment, Assessing Regional Integration in Africa VI. ECA: Addis Ababa.

Economic Commission for Africa (ECA). 2013b. Trade Facilitation from an African Perspective. Addis Ababa: ECA.

Fattah, Farag Abdel. 2000. "Trade Relation between Egypt and Common Market of Eastern and Southern Africa (COMESA)", Journal of African prospectivse (1). Cairo: General Authority for Information.

Food and Agriculture Organization (FAO). 2009. The State of Food Insecurity in the World, Economic Crisis: Impacts and Lessons Learned. Rome: FAO.

Karingi, Stephen, Nassim Oulmane, Mustpha Sadni- Jallab, Remi-lang, and Rom ainperez. 2006. "Assessment of the Impact of Economic Partnership Agreement between COMESA Countries and the European Union", African Trade Policy Centre (ATPC) Work in Progress (37). Addis Ababa: ATPC.

Metzger, Martina. 2008. "Regional Cooperation and Integration in sub-Saharan Africa", UNCTAD Discussion Papers (189). Geneva: United Nations.

Spence, Malcolm D, and Stephen N Karingi. 2011. "Impact of Trade Facilitation Mechanisms on Export Competitiveness in Africa", African Trade Policy Centre (ATPC), Work in Progress (85). Addis Ababa: ATPC.

United Nations Conference on Trade and Development (UNCTAD). 2009. "Strengthening Regional Economic Integration for Africa's Development", Economic Development in Africa Report. Geneva: United Nations.

United Nations Conference on Trade and Development (UNCTAD). 2013. UNCTAD Handbook of Statistics Year Book. Geneva: United Nations.

World Bank. 2013. Africa Development Indicators. Washington D.C: World Bank. 